\title{
Ação policial, política, luta camponesa e violência na região contestada entre o Espírito Santo e Minas Gerais
}

\section{Police action, politics, peasant struggle and violence in the contested region between Espírito Santo and Minas Gerais}

\author{
Edmilton da Silva* \\ Maria Cristina Dadalto*
}

\begin{abstract}
Resumo
Este artigo analisa a disputa territorial e por jurisdição política entre Minas Gerais e Espírito Santo que quase levou suas Polícias Militares à conflagração armada. 0 Contestado mineiro-capixaba também foi marcado por um quadro de violência em torno da posse, do uso e da propriedade da terra. Assim, por meio da história oral como metodologia, objetivamos analisar as tensões por divisa territorial na região contestada entre ambos os estados litigantes e os conflitos por terra e poder no período de 1940 a 1962, especialmente no município de Ecoporanga, ES, onde a situação apresentou contornos mais brutais. Na região contestada havia ainda uma íntima relação da Polícia Militar do estado com políticos locais e também com grandes proprietários de terra. Essa relação, além do próprio litígio fronteiriço, conduziu ao cometimento de inúmeros crimes contra a pessoa praticados, principalmente, pela Polícia Militar do Espírito Santo e por pistoleiros e jagunços. Há denúncias de vários assassinatos cometidos, em particular, contra posseiros. Após algumas das principais diligências policiais, o Poder Público, através da mídia jornalística, buscou qualificar a luta camponesa como uma atividade de bandidos, criminosos e fanáticos. Contudo, verificamos que o Contestado mineiro-capixaba viveu, de fato, uma violência que extrapolou os limites da própria condição humana e da vida em sociedade, em que as principais vítimas eram pessoas que buscavam terra para trabalhar.
\end{abstract}

Palavras-chave: Região contestada. Violência. Terra. Espírito Santo. Minas Gerais.

\section{Abstract}

This article analyzes the dispute of territorial and political jurisdiction between Minas Gerais and Espírito Santo that almost led its Military Police to the armed

\footnotetext{
${ }^{*}$ Mestre em História Social das Relações Políticas pela Universidade Federal do Espírito Santo. E-mail: edmilton.s@bol.com.br

** Doutora em Ciências Sociais pela Universidade do Estado do Rio de Janeiro. Professora dos Programas de Pós-Graduação em História e de Ciências Sociais e do Departamento de Ciências Sociais da Universidade Federal do Espírito Santo. E-mail: mcdadalto@gmail.com
} 
conflagration. The Minas Gerais-Espírito Santo conflict was also marked by a situation of violence around land tenure, use and ownership. Thus, through oral history as a methodology, we seek to analyze the tensions of the territorial border in the disputed region between the states and the conflicts over land and power in the period from 1940 to 1962, mainly in the municipality of Ecoporanga, ES, where the situation had more brutal aspects. In the contested region, there was also an intimate relationship between the State Military Police and local politicians and also with large landowners. This relationship, in addition to the border dispute itself, led to the committing of numerous crimes against the person, practised mainly by the Military Police of Espírito Santo and by gunmen and "jagunços". There are reports of several murders committed against invaders. After some of the main police actions, the Public Power, through the media, sought to qualify the peasant struggle as an activity of bandits, criminals and fanatics. However, we found that the Minas GeraisEspírito Santo Contest suffered, in fact, violence that exceeded the limits of the human condition itself and of life in the society in which the main victims were people looking for land to work.

Keywords: contested Region. Violence. Earth. Espírito Santo. Minas Gerais.

\section{Introdução}

As controvérsias por divisa territorial entre alguns estados brasileiros e, em especial, entre o Espírito Santo e Minas Gerais remontam à criação do sistema de capitanias hereditárias implantado no Brasil em 1534 e à descoberta de ouro no interior da colônia no final do século XVII. A Capitania do Espírito Santo, como as demais, não escapou à imprecisão dos critérios adotados para a partilha territorial e isso foi uma das causas das celeumas por questões de divisa pelas quais esse estado passaria no futuro. A descoberta de ouro no interior do Brasil no final do século XVII culminou com a criação da Capitania das Minas Gerais, em 1720, abrangendo a maior parte das terras capixabas na época.

A região contestada mineiro-capixaba abrangia muitos municípios dos dois estados. Esses eram incluídos ou retirados da disputa jurisdicional com base nos laudos e acordos firmados entre os litigantes desde o Auto Demarcatório de 1800 até o Acordo do Bananal, assinado em 15 de setembro de 1963, entre os governadores de Minas Gerais e Espírito Santo. Esse acordo pôs fim ao conflito. Segundo Pontes, ${ }^{1}$ a região era formada pelo território dos

${ }^{1}$ PONTES, W. T. Conflito agrário e esvaziamento populacional: a disputa do Contestado pelo Espírito Santo e Minas Gerais (1931 - 1970). 2007. 177f. Dissertação (Mestrado em história) - Programa de Pós-Graduação em História Social das Relações Políticas, Universidade Federal do Espírito Santo. Vitória, 2007, p. 45. Disponível em: <http://portais4.ufes.br/posgrad/teses/tese_3320_Walace_Tarcisio_Pontes.pdf>. Acesso em: 11 jan. 2020. 
atuais municípios de Alto Rio Novo, Mantenópolis, Barra de São Francisco, Água Doce do Norte, Ecoporanga, Ponto Belo e Mucurici, todos do lado capixaba, e Mantena, Itabirinha de Mantena, São João do Manteninha, Nova Belém, Ouro Verde de Minas e Ataleia, em terras mineiras. Essa porção do território brasileiro incrustado na Serra dos Aimorés abrange uma área total de $10.137 \mathrm{Km}^{2}$.

\section{Atuais Municípios que compunham a Regiáo do Contestado,} disputada por Minas Gerais e Espírito Santo
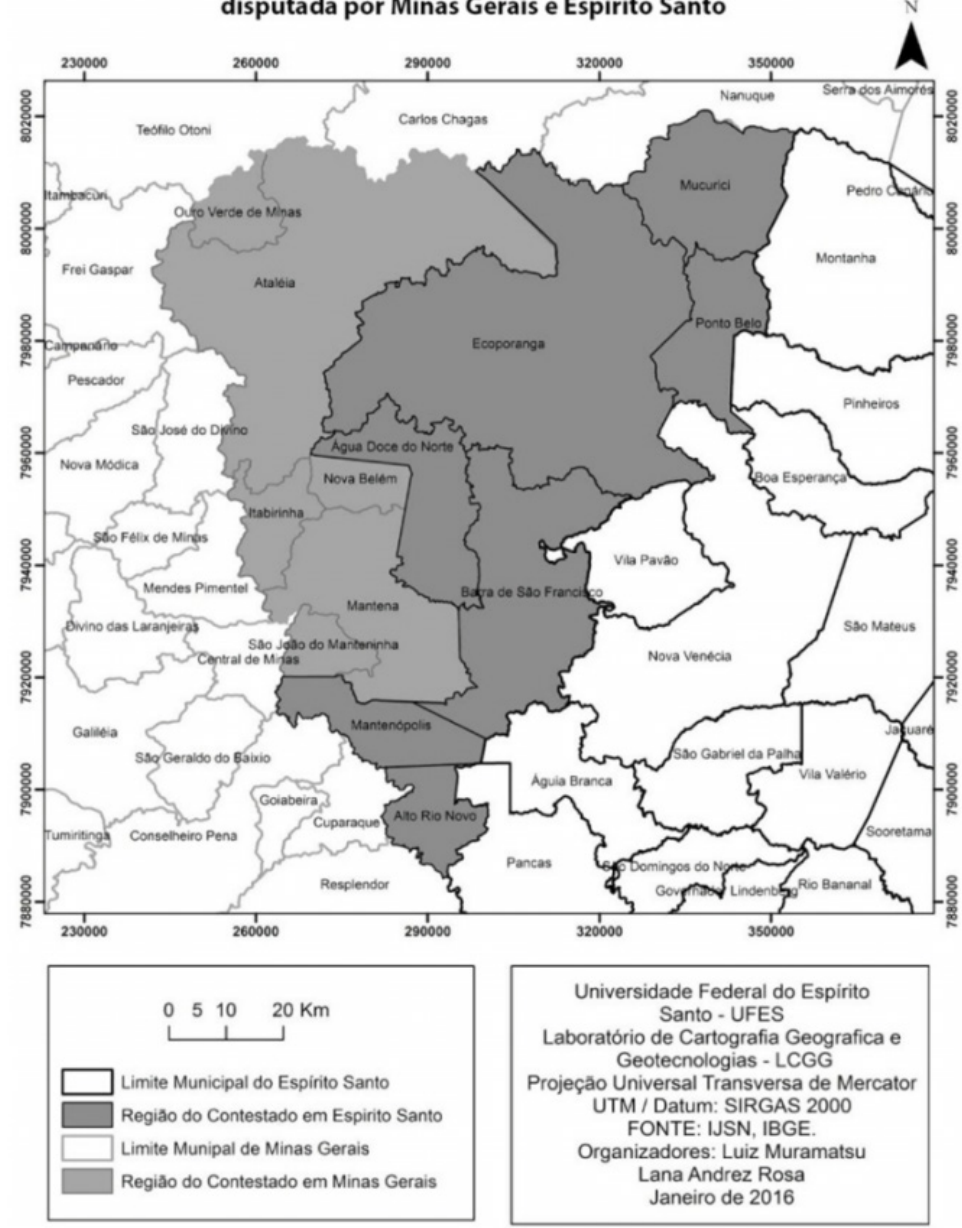

Municípios que compunham a região contestada²

\footnotetext{
${ }^{2}$ MURAMATSU, L. N. Movimento Camponês e Camponês em Movimento (Estudo histórico da violência na frente pioneira do Noroeste do Espírito Santo: 1950-1960). 2015. 342f. Tese (Doutorado em História) - Programa de Pós-graduação em História Social das Relações Políticas, Universidade Federal do Espírito Santo. Vitória, 2015, p. 105. Disponível em: <http://repositorio.ufes.br/bitstream/10/3560/1/tese_8792_LUIZ\%20 NOBORU\%20MURAMATSU.pdf>. Acesso em: 18 dez. 2019.
} 
O território contestado permaneceu praticamente sem exploração econômica e coberto por matas, consideradas prolongamentos da Mata Atlântica, até os anos 1930. A partir de então teve início o fluxo das correntes migratórias, atraídas pela qualidade das madeiras e por terras agricultáveis. Os grupos que para ali se dirigiram deslocaram-se até alcançar as terras banhadas pelos rios Cotaxé e Cricaré. Em consequência, picadas eram abertas na mata virgem, com posterior desflorestamento e ateagem de fogo, além da atividade predatória das madeireiras. Primeiro chegaram os posseiros, em seguida os chamados grileiros, portando títulos falsos de propriedade. ${ }^{3} \mathrm{O}$ direito estabelecido era o do uti possidetis. Assim, a luta pela terra na região contestada se estabeleceu entre dois polos extremamente desiguais e antagônicos: de um lado, uma aliança comum entre grileiros, latifundiários e indústria madeireira e, do outro, os posseiros, representados, muitas vezes, como invasores de terra.

Há que se ressaltar que a Polícia Militar do Espírito Santo (PMES), braço armado do estado na zona litigiosa, estava às voltas com uma dupla missão. Uma era garantir o espaço territorial capixaba, constantemente ameaçado pelo governo de Minas Gerais; a outra era preservar a ordem pública local. Contudo, a Polícia Militar capixaba disseminou violência e medo à medida que realizava diligências, algumas visivelmente ilegais, normalmente contra posseiros e supostos invasores.

Uma das mais conhecidas ações da Polícia Militar do Espírito Santo contra posseiros na zona contestada, especialmente no município de Ecoporanga, foi o ataque e destruição de um movimento liderado por Udelino Alves de Matos, em 1953. Outro episódio emblemático na história da luta camponesa no mesmo município diz respeito a uma diligência desastrosa da Polícia Militar capixaba realizada na Fazenda Rezende, distrito de Itapeba, em 1962. Essas ações geraram graves denúncias de violência e arbitrariedades policiais, alcançando, inclusive, repercussão em âmbito nacional. A Assembleia Legislativa do Espírito Santo (ALES) instaurou duas Comissões Parlamentares de Inquérito (CPIs) para apurar os fatos: uma em 1953 e outra em 1962. ${ }^{4}$

As apurações dessas CPIs, contudo, não modificaram a situação de violência vivida na região contestada. Não houve nenhuma mudança prática na relação entre grandes proprietários e posseiros nem na forma como esses últimos eram tratados pelas forças policiais. Na verdade, ao término dos

\footnotetext{
${ }^{3}$ NEVES, L. G. S.; PACHECO, R. Ecoporanga: da concepção à vida adulta. Vitória: Brasília Editora LTDA, 1992, pp. 43-45.

${ }^{4}$ Referimo-nos a tais documentos como CPI de 1953 e CPI de 1962. Essa última foi instaurada em 1961. Contudo, seus trabalhos foram iniciados, de fato, em 1962. Por isso, preferimos chamá-la de CPI de 1962.
} 
trabalhos de apuração, as CPIs procuraram inocentar o governo do estado e a Polícia Militar do Espírito Santo de quaisquer acusações do cometimento de arbitrariedades na região. A CPI de 1953, por exemplo, segundo Vilaça, ${ }^{5}$ finalizou seus trabalhos afirmando que o movimento camponês liderado por Udelino Alves de Matos era uma atividade de fanáticos e que, se não fosse a ação firme e enérgica da Polícia Militar, o distrito de Cotaxé em Ecoporanga teria se transformado numa "Nova Canudos".

Dado o pouco conhecimento historiográfico desse conflito no estado, a perspectiva teórico-metodológica encontra referência, sobretudo, na história oral, bem como nas poucas dissertações, fontes documentais e outros materiais de cunho bibliográfico encontrados. Além disso, utilizamos também o conceito de violência. Segundo Roberto da Mata, ${ }^{6}$ a violência é uma categoria sociológica complexa que faz parte da própria condição humana e da vida em sociedade. Para ele, a violência brasileira possui singularidades advindas do nosso sistema social, político e econômico e dos modos específicos de manifestação que a tornam diferente da violência inglesa, mexicana ou da colombiana, por exemplo.

Nosso objetivo é entender o processo histórico que conduziu a região contestada entre o Espírito Santo e Minas Gerais a vivenciar um panorama de tensões por divisa territorial e de conflitos por terra e poder no período de 1940 a 1962, culminando em uma violência que extrapolou os limites da própria condição humana e da vida em sociedade, chegando, mesmo, a atingir níveis de barbárie. Para tanto, foram realizadas dez entrevistas com policiais militares aposentados da Polícia Militar do Espírito Santo e com pessoas da sociedade local que ainda vivem, viveram ou trabalharam em municípios que compunham a região contestada.

Essas entrevistas são importantes porque nos permitiram compreender o cotidiano político e social vivenciado na região. Por meio delas foi possível perceber igualmente como aconteceram os principais episódios de violência contra a pessoa e, especialmente, contra os camponeses, bem como algumas das estratégias de defesa desses últimos contra a ação de pistoleiros e contra a arbitrariedade policial. Neste artigo utilizamos, em particular, as entrevistas com o policial militar Pedro Vicente ${ }^{7}$ e com os moradores locais Orlandina Ormezinda Silva, Nelsino Silvano de Oliveira e Geralda Maria Maciel.

\footnotetext{
${ }^{5}$ VILAÇA, As CPIs do esquecimento: uma pá... op. cit., pp. 18-19.

${ }^{6}$ MATA, R. “As raízes da violência no Brasil: reflexões de um antropólogo social” In PAOLI. M. C. e tal. Ed (s). A violência brasileira. São Paulo: Brasiliense, 1982.

${ }^{7}$ Pedro Vicente é policial militar reformado da PMES. Trata-se de um nome fictício.
} 
Ressaltamos que nossos entrevistados foram citados nominalmente porque alguns deles, dentre os quais Orlandina Silva, Nelsino Silvano de Oliveira e Geralda Maria Maciel já foram identificados por seus verdadeiros nomes em outras pesquisas sobre o Contestado mineiro-capixaba. Esclarece-se, inclusive, que alguns entrevistados fazem questão de serem referenciados por seus nomes de batismo.

Além das fontes orais, utilizamos as CPIs de 1953 e 1962 instauradas pela Assembleia Legislativa do Espírito Santo. Essas fontes são importantes porque contêm diversas declarações de policiais militares, além de inúmeros depoimentos de supostas vítimas e testemunhas das ilegalidades cometidas por agentes públicos, permitindo, desse modo, que se tenha uma visão dos fatos sob a ótica dos excluídos.

Nosso corpus documental é formado ainda por Boletins Diários (BD) da Polícia Militar do Espírito Santo da década de 1950. Esses boletins eram publicados diariamente e, em sua maioria, são fontes inéditas em nossa historiografia. Logo, possibilitam ter uma visão parcial do cotidiano da Polícia Miliar capixaba na localidade. Ademais, descrevem os vários envios de tropas policiais para a zona contestada, contribuindo assim para o melhor entendimento do nosso objeto de pesquisa. Também utilizamos alguns artigos jornalísticos publicados nos jornais Folha do Povo e A Gazeta. ${ }^{8}$ A escolha desses jornais, bem como de algumas matérias por eles veiculadas, justifica-se tanto pelo valor qualitativo dos fatos abordados quanto pelo conteúdo dos discursos reportados. Alguns desses discursos foram utilizados de forma a legitimar as arbitrariedades do poder e a desqualificar a luta camponesa na região.

\section{Polícia Militar, política e poder}

A Polícia Militar do Espírito Santo começou a ocupar o Contestado mineiro-capixaba a partir de meados da década de 1930, quando a região foi palco das primeiras incursões de autoridades mineiras por conta do litígio fronteiriço entre ambos os estados litigantes. Mas a histórica questão territorial entre Minas e Espírito Santo possuía outras vertentes, a saber: direito de nomear autoridades, explorar riquezas naturais, vender e legalizar terras devolutas e cobrar impostos, entre outras. Por isso, as incursões da Polícia Militar de Minas Gerais (PMMG) em terras capixabas logo passaram à tentativa de ocupação territorial.

\footnotetext{
${ }^{8}$ Trata-se de um dos jornais de maior circulação no Espírito Santo desde a época do Contestado mineiro-capixaba. Neste trabalho utilizamos alguns dos seus artigos publicados nas décadas de 1940, 1950 e 1960.
} 
Noticiadas, principalmente, pela imprensa (jornais A Gazeta e A Tribuna, ${ }^{9}$ sobretudo, nas décadas de 1940 e 1950) em Vitória, capital do estado, como invasão do território capixaba, as investidas da Polícia Militar mineira na zona contestada traziam inquietação ao governo capixaba. Em decorrência, a Polícia Militar do Espírito Santo deslocou grande quantidade de policiais para reforçar seu efetivo naquela região. Os constantes embates envolvendo fazendeiros, jagunços e posseiros, além da resistência, muitas vezes armada, de posseiros contra policiais militares também são fatores que contribuíram para o reforço no efetivo policial daquela localidade.

Em abril de 1948 os jornais A Gazeta e A Tribuna noticiaram a invasão de Barra de São Francisco por forças mineiras. O governador Carlos Lindenberg (1947-1951) enviou seu contingente policial militar para a região, fez minucioso relatório dos fatos a Milton Campos, governador de Minas Gerais, e ao presidente da República, Eurico Gaspar Dutra. A Assembleia Legislativa capixaba, por sua vez, instaurou uma CPI para investigar os acontecimentos. Também em 1957, especialmente nos meses de julho e agosto, o Governo do Estado deslocou efetivo policial, por diversas vezes, para o município de Barra de São Francisco, já então transformado em sede do Comando da Polícia Militar do Espírito Santo no Contestado.

Demoner ${ }^{10}$ afirma que, assim como em 1948, no ano de 1957 a região contestada viveu clima de guerra. Nas montanhas a oeste de Barra de São Francisco foram feitas trincheiras guarnecidas ininterruptamente por 34 dias consecutivos. Tratada pela Polícia Militar capixaba como a "fase aguda da questão litigiosa Minas-Espírito Santo" ${ }^{11}$ e como "situação de emergência", ${ }^{12}$ o novo período marcado pelo intenso deslocamento de forças policiais para a zona contestada, tanto por parte do Espírito Santo quanto por Minas Gerais, teve origem no pretenso direito de ambos os estados a cobrarem impostos na região.

Vivia-se um período próximo da colheita do café naquele ano de 1957, em que talvez haveria uma das maiores safras da região do Contestado. 0 Espírito Santo possuía dois postos fiscais em Água Doce: o posto do Distrito de

\footnotetext{
${ }^{9} \mathrm{O}$ jornal A Tribuna, assim como o A gazeta, também possuía grande circulação no Espírito Santo na época do Contestado mineiro-capixaba e igualmente publicou várias reportagens sobre os acontecimentos naquela região. No entanto, seu acervo sofreu um incêndio na noite de 25 de maio de 1981. Por isso, ficamos impossibilitados de consultar suas reportagens mais significativas em nossa pesquisa.

${ }^{10}$ DEMONER, S. M. História da Polícia do Espírito Santo, 1835 - 1985. Vitória, 1985, p. 103.

${ }^{11}$ POLÍCIA MILITAR DO ESPÍRITO SANTO. Boletim Diário nº 178. Vitória: Arquivo Geral do Quartel do Comando Geral, 1957, p. 945.

${ }^{12}$ POLÍCIA MILITAR DO ESPÍRITO SANTO. Boletim Diário n189. Vitória: Arquivo Geral do Quartel do Comando Geral, 1957, p. 986.
} 
São João e o de Café Ralo. Autoridades mineiras, objetivando cobrar impostos sobre essa produção, construíram um desvio canalizando o escoamento do café direto para Mantena, anulando totalmente os postos fiscais capixabas. Nesse momento, Mantena ${ }^{13}$ já estava sob ocupação da polícia mineira. Civis mineiros exaltados atearam fogo no posto fiscal de Café Ralo e destruíram também os outros postos capixabas de Itabira e Ariranha, em Mantenópolis.

O litígio fronteiriço provocava profundas alterações na rotina administrativa dos estados envolvidos, bem como na de suas polícias. A Polícia Militar do Espírito Santo, por exemplo, além de precisar manter destacamentos nas pretensas divisas do estado para impedir o avanço da polícia mineira, também deveria realizar a manutenção e a preservação da ordem pública local, pelo menos em seu lado do Contestado. Para isso, estava estruturalmente organizada em delegacias e subdelegacias nas cidades e distritos, respectivamente. Na maioria das vezes, esses estabelecimentos eram administrados por um policial militar nomeado em comissão (cargo de confiança do governo) para a função de delegado ou subdelegado. Os delegados de polícia tinham a função de polícia judiciária. Assim, deveriam apurar as denúncias de delitos e os crimes cometidos, encaminhando os devidos inquéritos à Justiça, onde seriam tomadas as providências cabíveis.

Na região contestada, em particular em Barra de São Francisco, estava sediada também uma Delegacia de Capturas ${ }^{14}$ ou simplesmente "Captura", como era mais conhecida popularmente. Seu delegado, um oficial da Polícia Militar nomeado em comissão, diferentemente dos delegados municipais, não tinha poder legal para instaurar inquéritos e investigar crimes ou denúncias de ilícitos. A Lei no 719/1953, segundo Gaviorno, Sperandio e Ferreira, ${ }^{15}$ primeira lei de organização básica da Polícia Civil capixaba, evidenciava que eram competências das Delegacias de Captura a captura de condenados, suspeitos de furto de animais, acusados, réus foragidos, criminosos evadidos, desertores e insubmissos, quando requisitada pelas autoridades civis e militares; e também cumprimento de mandados de prisão preventiva e administrativa.

\footnotetext{
${ }^{13}$ Este município foi criado com o nome de Gabriel Emílio, em 1937, por ato do capixaba Eugênio Neves Cunha. Os mineiros nunca aceitaram tal denominação. Assim, o município era chamado Gabriel Emílio pelos capixabas e Mantena pelos mineiros. Nome que, aliás, continua até os dias atuais. MORAES, C. Como nasceram cidades no Espírito Santo. Vitória: [s.n.] 1954, p. 78.

${ }^{14}$ De acordo com a Lei no 719/1953 havia três Delegacias de Capturas no Estado: uma na Zona norte com sede em Barra de São Francisco; uma na Região central com sede em Afonso Cláudio e outra delegacia na Zona sul com sede em Alegre. GAVIORNO, G. V. S. C.; SPERANDIO, J. A.; FERREIRA, P. C. Uma nova estrutura para a Polícia Civil. 2001. 62 f. Monografia (Curso de Especialização em Segurança Pública) - CCJE/CIESP, Universidade Federal do Espírito Santo, Vitória, 2001, pp. 18-19.

${ }^{15}$ Ibidem, p. 17.
} 
Na realidade, essa lei, no que se refere às Delegacias de Captura, apenas regulamentou aquilo que já era feito na prática. Espécie de "corpo de elite", as "Capturas" eram formadas apenas por policiais de confiança e escolhidos dentre os mais corajosos. Normalmente, constituíam-se de um pequeno grupo de seis a oito policiais militares. Os delegados de captura, na maioria das vezes nomeados para "missões" específicas ou para atender a demandas em lugares e em momentos determinados, possuíam liberdade para escolher, entre os policiais militares, aqueles que fariam parte do seu grupo.

A "Captura" era temida, sobretudo, pela violência que praticava durante suas diligências e pelo terror que representava. Isso ocorria porque as operações policiais no Contestado, na maioria das vezes, eram marcadas pela arbitrariedade cometida, principalmente, contra posseiros, supostos invasores de terra e acusados do cometimento de furto de animais. Além disso, havia a inegável relação entre polícia, políticos locais e grandes proprietários, de modo que, no imaginário popular, havia a certeza de que, nos conflitos entre as pessoas comuns da sociedade, como os posseiros, por exemplo, e os poderosos da região, a polícia sempre faria com que o fiel da balança pendesse para o lado desses últimos.

Do lado de Minas Gerais, o líder político de maior destaque no período do litígio fronteiriço com o Espírito Santo foi José Fernandes Filho, prefeito nomeado do município de Mantena de 1944 até 1945, quando teve de deixar a prefeitura por conta do fim da ditadura de Getúlio Vargas. Retornou depois, como prefeito eleito, para o mandato de 1948 a $1951 .{ }^{16}$ José Fernandes Filho foi acusado de ser "[...] o maior instigador da questão de limites [...]" mineiro-capixaba ${ }^{17}$ e o "[...] dono político da região [...]" contestada em Minas Gerais, ${ }^{18}$ quando "civis exaltados" mineiros atearam fogo e destruíram os postos fiscais de Café Ralo e Ariranha, em Mantenópolis.

As principais lideranças políticas capixabas, comparadas a Fernandes Filho, eram na esmagadora maioria formadas por líderes políticos provenientes de grandes famílias oligárquicas do interior. É o caso, entre outros, dos três governadores do estado (Jones dos Santos Neves, Carlos Lindenberg e Francisco Lacerda de Aguiar ${ }^{19}$ no período de acirramento da disputa

\footnotetext{
${ }^{16}$ Informações colhidas no site oficial da Prefeitura municipal de Mantena, MG. Disponível em: <https:// www.mantena.mg.gov.br/historia-do-municipio/>. Acesso em: 14 fev. 2020.

${ }^{17}$ MOVIMENTAÇÃo de tropas na zona contestada. A Gazeta, Vitória, 30 jul. 1957, p. 1.

${ }^{18}$ OCORRÊNCIAS na zona litigiosa. A Gazeta, Vitória, 23 jul. 1957, p. 1.

${ }^{19}$ Jones dos Santos Neves (1943-1945), como interventor indicado por Getúlio Vargas; Carlos Lindenberg (1947-1951), Jones dos Santos Neves (1951-1955), como governador eleito. Francisco Lacerda de Aguiar (1955-1959), novamente Carlos Lindenberg (1959-1962) e, de novo, Francisco Lacerda de Aguiar (1963-1966).
} 
jurisdicional entre Minas e Espírito Santo e de maior repressão policial aos movimentos de luta pela terra na região. Os que melhor representaram esse momento foram Jones dos Santos Neves e Carlos Lindenberg. Foi na administração de Jones dos Santos Neves que a Polícia Militar capixaba destruiu o movimento camponês liderado por Udelino Alves de Matos, em 1953, ao passo que Carlos Lindenberg era o governador do estado quando da ação policial que pôs fim aos acontecimentos iniciados na fazenda Rezende, em 1962.

Entretanto, em termos políticos, segundo Achiamé, ${ }^{20}$ Lindenberg soube muito bem "cumprir a palavra empenhada, não trair os correligionários e, sempre que possível, dar atenção pessoal ao eleitor". No mesmo sentido, Almeida ${ }^{21}$ assevera que Carlos Lindenberg "nunca deixou de responder a uma carta, à mão, mesmo que fosse para negar um pedido". Contudo, quanto à suposta lealdade aos amigos e honra à palavra empenhada, ao que parece, Carlos Lindenberg teria deixado a desejar, pelo menos, na região contestada, onde a violência refletida nos crimes de mando como meio de luta por terra e voto falava mais alto. Orlandina Ormezinda Silva, ${ }^{22}$ esposa de José Francisco da Cruz, ${ }^{23}$ disse que seu marido foi assassinado covardemente na cidade de Ecoporanga, por policiais militares, em dezembro de 1960. Que, nesse ano, Carlos Lindenberg era governador do estado pela segunda vez (1959-1962) e teria garantido proteção e apoio político a José da Cruz. Todavia, segundo Orlandina, nada foi feito para desvendar o homicídio do "amigo" e prender os acusados, motivo pelo qual a morte do seu marido ficou totalmente impune.

[...] eles mataram meu marido covardemente. A polícia foi quem o matou. Quem o matou foi o cabo Antônio e o tal de João Dantas. ${ }^{24}$ Então, o Carlos Lindenberg era governador. O José era do PSD naquela época, negócio de política, e ele, [Carlos Lindenberg] falava que dava todo o apoio. No entanto..., quando ele [Carlos Lindenberg] vinha aqui, ficava na nossa casa. Se o bandido fosse para lá, ele vinha para cá. Ninguém tomou nenhuma [providência], até que o processo caiu. [...] foi extinto [...]. O Dr. Carlos Fernando Lindenberg [...] disse que faria

\footnotetext{
${ }^{20}$ ACHIAMÉ, F. O Espírito Santo na era Vargas (1930 - 1937). Rio de Janeiro: editora FGV, 2010, p. 222.

${ }^{21}$ ALMEIDA, A. Carlos Lindenberg: um estadista e seu tempo. Vitória: Arquivo Público do Espírito Santo, 2010, p. 160. Disponível em: <https://ape.es.gov.br/Media/ape/PDF/Livros/Livro_Carlos_Lindenberg. pdf>. Acesso em: 25 fev. 2020.

${ }^{22}$ SILVA, Orlandina Ormezinda. Violência e política no Contestado. 2018. Entrevista concedida na cidade de Ecoporanga, ES, em 19 de abril de 2018.

${ }^{23}$ José da Cruz, como era mais conhecido, foi líder do PSD local, candidato a prefeito por Ecoporanga e era dirigente da Associação dos Lavradores e Trabalhadores Agrícolas do Espírito Santo (ALTAES). DIAS, L. N. Massacre em Ecoporanga: lutas camponesas no Espírito Santo. Vitória: Editora Cooperativa dos Jornalistas do Espírito Santo. 1984, pp. 86-87.
}

${ }^{24}$ Cabo Antônio e João Dantas são nomes fictícios. 
tudo e não fez nada. Nunca teve nenhum..., não prenderam nenhum. Os homens morreram lá, mas foi de doença. [...]. Só o que eles fizeram foi tirá-los daqui para não haver qualquer confusão. Eu não tinha coragem de matar ninguém, não. Eu não tenho coragem. ${ }^{25}$

Além da indignação com o assassinato de José da Cruz; com a falta de empenho por parte do governador Carlos Lindenberg, que lhe teria prometido "apoio"; com as demais autoridades porque, supostamente, nada fizeram para prender e punir os criminosos e, em particular, com a subsequente impunidade, as palavras de Orlandina Silva revelam outra face da política da época: o envolvimento de policiais militares com crimes de mando na região. 0 policial militar reformado Pedro Vicente ${ }^{26}$ que trabalhou, praticamente, toda sua vida profissional no Noroeste capixaba, quando questionado sobre a ação de pistoleiros na localidade, assegurou que "[...] todos eles (pistoleiros) eram amigos da gente e tudo. Há muitos que estão aqui em Ecoporanga ainda. Não é bom falar os nomes deles [...]".

Os crimes violentos, entre eles os crimes de mando praticados por pistoleiros, contam, normalmente, com uma espécie de código de honra ou código de silêncio, cuja consequência mais nefasta, após o cometimento do próprio delito, é, sem dúvida, a sua total impunidade. $\mathrm{O}$ assassinato de José da Cruz, por exemplo, está longe de ser o único caso ocorrido no Contestado em que os executores ficaram completamente impunes.

A complexa articulação entre pistolagem, atividade policial e política era apenas uma das faces da violência no Contestado. Violência, aliás, conforme observa Roberto da Mata, ${ }^{27}$ entendida como algo dinâmico e que "se reflete e de fato se concretiza, encarnando-se tanto na polícia quanto no criminoso; tanto na norma que diz 'não pode' quanto na antinorma que diz 'eu quero' [...]”. Mas, se entendemos que a violência, dentre outros fenômenos sociológicos, é uma das formas pelas quais uma sociedade se revela, teremos, então, que tomar como ponto de partida suas singularidades e modos específicos de manifestação em cada sistema.

No que toca, em particular, ao Espírito Santo, há uma acumulação social da violência relacionada diretamente com a história do estado e com sua baixa capacidade coercitiva. Por isso, havia uma grande concentração de armas nas mãos de terceiros, de modo que o governo estadual não era o único a

\footnotetext{
${ }^{25}$ SILVA, op. cit.

${ }^{26}$ VICENTE, Pedro. Cotidiano policial. 2018. Entrevista concedida na cidade de Ecoporanga, ES, em 20 de abril de 2018.
}

${ }^{27}$ MATA, op. cit., pp. 12-15. 
monopolizar o uso da força. ${ }^{28}$ Ademais, o Contestado mineiro-capixaba, como região de fronteira que vivia sob dupla jurisdição política, aliada, especialmente, à intensa onda migratória da qual fez parte e às disputas por terra e poder o conduziram a vivenciar um tipo peculiar de violência. Praticada por policiais, notadamente os militares, bem como por pistoleiros e jagunços, essa violência era o mecanismo segundo o qual líderes políticos locais e grandes proprietários de terra impunham sua vontade e exerciam seu poder contra adversários políticos e contra os inumeráveis camponeses que migraram para a região à procura de terras devolutas para cultivar.

\section{Luta camponesa e violência}

A intensa migração para o Contestado mineiro-capixaba o transformou em lugar da mais variada diversidade humana. Nele havia:

Gente em busca de trabalho e riqueza. Trabalhadores, empresários. Aventureiros
em geral. Gente bem intencionada. Mal intencionada também. Campeões
do machado. Maratonistas do traçador. Simples agricultores. Motoristas.
Mecânicos. Comerciantes. Prestadores de serviços. Fugitivos das autoridades
judiciais, que se tornavam mão de obra armada a serviço de quem pagasse
melhor. ${ }^{29}$

Entretanto, foram os posseiros que enfrentaram poderosos fazendeiros e seus jagunços, inúmeros grileiros e, principalmente, a Polícia Militar do Espírito Santo. Embora essa situação fosse encontrada em todo o Norte do estado, foi, de fato, em Ecoporanga que a luta camponesa por terra ganhou contornos mais cruentos. Em meio a essa batalha extremamente desigual, tendo a violência, em suas variadas formas, como resultado mais evidente, que, em meados da década de 1940, surgiu em Cotaxé, distrito de Ecoporanga, o baiano Udelino Alves de Matos.

Udelino era dotado de especial habilidade para atuar no campo político, além de possuir uma boa dose de perspicácia, senso de oportunidade e natural simplicidade. Essas qualidades, aliadas a um discurso que agregava o apelo à terra e preceitos religiosos, fizeram dele o primeiro e o mais representativo líder de um movimento camponês que se estendeu de meados da década de 1940 até os primeiros anos da década de 1950. Udelino lutava não apenas pela terra, mas também pela efetiva permanência dos camponeses pobres naquela

\footnotetext{
${ }^{28} \operatorname{COSTA}$, M. A. B. Vítimas que choram: trajetórias de coerção, acumulação social e empreendedorismo violento no Espírito Santo. São Paulo: Opção livros, 2016.

${ }^{29}$ HASSE, G. “Faroeste caboclo: meus colegas lavradores” In Século, Vitória, ano 1, n. 6, 2000, p. 9.
} 
região conflagrada onde seus direitos eram constantemente violados. ${ }^{30} \mathrm{Seu}$ objetivo era criar um novo ente federativo naquela zona contestada, o Estado União de Jeová, lugar em que todos os posseiros teriam seu pedaço de chão para trabalhar e em que ele, Udelino, seria governador. Criado às margens do córrego Canela de Ema, em Cotaxé (antiga Pedra da Viúva), o Estado União de Jeová contava com agentes públicos nomeados, além de símbolos representativos de poder: bandeira e hino. Características, aliás, dos estados federados. ${ }^{31}$

Udelino criticava os governos do Espírito Santo e de Minas Gerais e propunha o não pagamento de impostos, além de ameaçar e enfrentar autoridades locais naquela região onde valia a lei do mais forte. Em seu projeto, Udelino não estava só. Contava com o apoio de Cristolino Cardoso, prefeito de Barra de São Francisco e apoiador dos posseiros da região; do padre Elauro Zacarias de Oliveira, vigário de Barra de São Francisco e do deputado federal Wilson Cunha, do Partido Social Progressista (PSP).

Em ofício do encarregado de medições, Manoel de Tudéia, ao delegado de Terras e Colonização de São Domingos, Arnaldo Gomes de Oliveira, Udelino foi acusado de chefiar um grupo de 450 pessoas, todas bem armadas. Em outra ocasião, quando foi ao Distrito Federal (RJ) tentar falar com Getúlio Vargas, Udelino levou consigo um memorial com 866 assinaturas de agricultores. ${ }^{32}$ Tratava-se de uma evidente demonstração de liderança e prestígio pessoal ao representar os anseios, agruras e queixas dos camponeses.

Udelino também possuía uma espécie de "tropa de choque" composta por um grupo de aproximadamente 18 homens de confiança, entre os quais se destacavam dois jagunços principais: João Piedade e Deroci Laurindo da Silva, mais conhecido por Jorge Come-cru. Foi a este último que Udelino confiou o comando de sua "ação guerreira". ${ }^{33}$ O grupo de Udelino invadia fazendas exigindo a documentação das terras, ameaçava e expulsava fazendeiros da região e cometia assassinatos. Nesse sentido, evidencia-se pelo menos um caso: o assassinato de Izaias Conceição, ${ }^{34}$ morto em 14 de fevereiro de 1953

\footnotetext{
${ }^{30}$ GARCIA, E. R. Do Estado União de Jeovah à União dos Posseiros de Cotaxé: transição e longevidade. 2015. 203f. Dissertação (Mestrado em História) - Programa de Pós-Graduação em História Social das Relações Políticas, Universidade Federal do Espírito Santo. Vitória, 2015, p. 84. Disponível em: <http://repositorio.ufes.br/ bitstream/10/3531/1/tese_7635_DISSERTA\%c3\%87\%c3\%830\%20ELIO\%20\%20RAMIRES20151028-142025. pdf>. Acesso em: 10 dez. 2019.

${ }^{31}$ VILAÇA, Cotaxé: a reinvenção... op. cit.

${ }^{32}$ DIAS, op. cit., pp. 51-53.

${ }^{33}$ VILAÇA, Cotaxé: a reinvenção... op. cit., p. 116.

${ }^{34}$ Izaias era administrador da fazenda de Gustavo de Oliveira e foi morto na ocasião em que um grupo de 18 homens chefiados por Udelino, invadiu a propriedade onde Izaias trabalhava. DIAS, op. cit., pp. 54-55.
} 
com um tiro nas costas disparado por Jorge Come-cru. Das informações levantadas, esse foi o homicídio de maior repercussão cometido pelo braço direito de Udelino.

Suas atividades e as de seus seguidores logo chamaram a atenção dos governos mineiro e capixaba. Segundo Vilaça, ${ }^{35}$ houve até um armistício entre os governadores Juscelino Kubitschek, de Minas Gerais e Jones dos Santos Neves, do Espírito Santo, para combaterem o inimigo comum através de suas polícias. A "missão" final coube à Polícia Militar do Espírito Santo. O escolhido para pôr fim ao sonho de Udelino e de seus seguidores foi o major Djalma Borges, que atuava no Contestado desde o início de 1938. Tratava-se de um policial experiente tanto em lidar com a polícia mineira, em questões de divisa territorial, quanto em diligências envolvendo posseiros. Conhecido e temido, muitas vezes bastava a notícia de que chegaria a determinado distrito para demover os camponeses de qualquer intenção.

Na manhã do dia 24 de fevereiro de $1953^{36}$ o grupamento de Djalma Borges - composto por 23 homens - chegou a União de Jeová e tomou a Casa de Tábua, sede administrativa de Udelino. A polícia não encontrou qualquer resistência, e 17 agricultores foram presos..$^{37}$ Os policiais puseram fogo no "barracão" e instalou-se o terror, com espancamentos brutais. ${ }^{38} \mathrm{O}$ objetivo era saber o paradeiro de Udelino e de seus principais assessores, jagunços com quem ele contava. $O$ assassinato de Izaias Conceição também não foi esquecido. As técnicas de investigação policial eram conhecidas na região: surras de cipó ou de umbigo de boi e coronhadas de fuzil faziam qualquer um falar.

Udelino e mais cinco de seus homens (Jorge Come-cru, Sebastião Raimundo, João Piedade, José Maria Furtado e José Moreira Sampaio) conseguiram escapar do cerco policial. Na fuga, pretendiam chegar à Vila dos Paulistas, onde, por certo, encontrariam ajuda. ${ }^{39} \mathrm{Na}$ noite do dia 26 de fevereiro, portanto, dois dias após a tomada de União de Jeová, ao passarem pelo Patrimônio de Santa Terezinha, tiveram confronto com uma patrulha policial. Nessa ocasião, o sargento Altivo - uma das autoridades ameaçadas por Udelino - saiu ferido por um tiro de espingarda de "carregar pela boca". Segundo relatório do Inquérito Policial instaurado para apurar os fatos, o disparo teria

\footnotetext{
${ }^{35}$ VILAÇA, “Rápido no gatilho, certeiro na...” op. cit., p. 24.

${ }^{36}$ DIAS, op. cit., p. 56.

${ }^{37}$ VILAÇA, “Rápido no gatilho, certeiro na...” op. cit., p. 22.

${ }^{38}$ ESPÍRITO SANTO (Estado). Assembleia Legislativa. Comissão Parlamentar de Inquérito. (CPI) de 1953. Vitória, 1953.

${ }^{39}$ PONTES, op. cit., p. 148.
} 
sido efetuado por Sebastião Raimundo, morto no confronto. Jorge Come-cru foi preso, ferido com um tiro na coluna. Do lado da polícia, além do sargento Altivo, o civil Pedro Praxedes da Silva, qualificado no inquérito como "auxiliar da polícia”, também saiu ferido..$^{40} \mathrm{Na}$ verdade, esse civil era um bate-pau como outros tantos, que "auxiliavam" a polícia em determinadas diligências.

Contudo, Udelino conseguiu escapar. Chegou à propriedade de Genuíno da Silva Gama, em Galileia, MG, onde permaneceu por cinco dias. Recebeu ajuda e roupas novas e depois partiu dizendo que, de qualquer maneira, iria relatar os acontecimentos a Getúlio Vargas. Nunca mais foi visto na região, mas o fim do sonho Udelinista ${ }^{41}$ não significou o fim da luta camponesa em Ecoporanga. No ano seguinte à destruição de União de Jeová, retirantes vindos de Galileia, entre eles Genuíno da Silva Gama, já estavam em Cotaxé. ${ }^{42}$

Nesse período os posseiros enfrentavam as ameaças de Francisco Modesto de Meneses, fazendeiro que se dizia dono de uma área muito maior do que, de fato, havia requerido ao governo capixaba. Genuíno havia ingressado no Partido Comunista do Brasil (PCB) e se tornado referência de liderança para a polícia e para os camponeses..$^{43} \mathrm{O} \mathrm{PCB}$, partido na clandestinidade naquela época, atuava, conforme aponta Garcia, ${ }^{44}$ "no sentido da conscientização do direito ao uso da terra e da organização dos posseiros [...]" - inclusive, posseiros remanescentes do período udelinista. Sua atuação se deu através da União dos Posseiros de Cotaxé (UPC), fundada em novembro de 1954. Há, portanto, a partir de então, uma nova característica a ser acrescentada ao movimento camponês: a luta se torna eminentemente política.

Todavia, os espancamentos, prisões e assassinatos de posseiros continuaram. No segundo semestre de 1957 o tenente Jadir Resende, recém-nomeado delegado de Captura da Zona Norte, ${ }^{45}$ submeteu camponeses situados nas terras que supostamente seriam de Francisco Modesto de Meneses a uma

\footnotetext{
${ }^{40}$ POLÍCIA MILITAR DO ESPÍRITO SANTO. Boletim Diário nº 96. Vitória: Arquivo Geral do Quartel do Comando Geral, 1953, p. 361.

${ }^{41}$ Utilizamos o termo "udelinista" como seguidores de Udelino de Matos. Às vezes, também o utilizamos como sinônimo de "Estado União de Jeová" ou simplesmente, "União de Jeová". Acreditamos que em qualquer um dos casos evidencia-se o fato de que Udelino possuía seguidores. Logo, exercia posição de liderança junto aos posseiros de Cotaxé ou, pelo menos, junto a uma parcela desses trabalhadores.

${ }^{42}$ DIAS, op. cit., pp. 63-64.

${ }^{43}$ Ibidem, pp. 66-71.

${ }^{44}$ GARCIA, op. cit., pp. 110-111.

${ }^{45}$ POLÍCIA MILITAR DO ESPÍRITO SANTO. Boletim Diário nำ162. Vitória: Arquivo Geral do Quartel do Comando Geral, 1957, p. 852.
} 
das situações mais humilhantes e desprezíveis da história do Contestado. Segundo informa Dias, ${ }^{46}$

Uma centena de posseiros ouve a música acompanhada por um sanfoneiro da Polícia Militar destacado em Cotaxé: [...] Eles dançam durante várias horas. Nus e desajeitados, homens, mulheres e crianças circulam dentro do curral da fazenda de Francisco Modesto. Encostados na cerca de arame, em torno do sanfoneiro, estão os componentes da captura comandada pelo tenente Jadir Resende, recentemente nomeado delegado de Ecoporanga. Em fila, os posseiros continuam dançando. [...] A fila é assim: sem distinção de sexo ou idade, os lavradores requebram em círculo, sob ameaça de armas, cada um com uma mão sobre o ombro do outro e com um dedo da outra mão na bunda do companheiro da frente. De vez em quando um chicote estala nas costas dos que se revoltam contra a humilhação. Estes são obrigados a lamber pisaduras dos animais presos no curral. Os militares riem e, impotentes, muitos moradores do povoado assistem ao quadro.

Um desses moradores era Nelsino Silvano de Oliveira, ${ }^{47}$ que ainda se lembra do acontecido e da música ${ }^{48}$ cantada durante o horrendo espetáculo. Esse episódio, em que posseiros foram "presos" no curral, também foi confirmado anos depois pelo próprio tenente Jadir em entrevista a Vilaça: ${ }^{49}$ "Prendi posseiros num curral, lá em Cotaxé. Muita gente mesmo. A notícia veio parar em Vitória. Foi um problemão".

A despeito de fatos como esse, o movimento camponês de luta pela terra se fortaleceu no estado a partir do I Congresso Estadual dos Lavradores, realizado em Vitória, em novembro de 1957 e da criação, ao término deste, da Associação dos Lavradores e Trabalhadores Agrícolas do Espírito Santo (ALTAES). Entretanto, em novembro de 1959, o movimento sofreu um duro golpe com a morte, em virtude de uma enfermidade, do seu líder, Genuíno da Silva Gama. Mas seus filhos, Zé Genuíno, Romualdo, Benício e Antônio, que também faziam parte do $\mathrm{PCB},{ }^{50}$ continuaram atuando na luta camponesa. Tornaram-se, por isso, alvos da Polícia Militar, de fazendeiros e de seus

\footnotetext{
${ }^{46}$ DIAS, op. cit., pp. 69-70.

${ }^{47}$ OLIVEIRA, Nelsino Silvano de. Testemunha da violência. 2018. Entrevista concedida no Assentamento Miragem em Ecoporanga, ES, em 19 de abril de 2018.

${ }^{48}$ Tratava-se da "música do caranguejo". Os caranguejos eram os próprios posseiros que "dançavam" enfileirados e a letra da "música" dizia basicamente que nas terras do "Franquin", Francisco Modesto de Meneses, "não é lugar para ninguém roubar". No documentário "O Efêmero estado União de Jeovah" (52'30" - 53'04") é possível assistir Nelsino de Oliveira cantado a referida "música". O EFÊMERO estado União de Jeovah. Direção e produção: Joel Zito Araújo. Vitória: L.C.A. Produções, 1999. Disponível em: <https://www.youtube.com/watch?v=oVaamQQ2Bjs>. Acesso em: 01 mar. 2020.

${ }^{49}$ VILAÇA, “Rápido no gatilho, certeiro na...” op. cit., p. 19.

${ }^{50}$ DIAS, op. cit., p. 71.
} 
jagunços. Antônio Genuíno foi assassinado numa tocaia em 1962. Sua morte foi atribuída aos capangas de Lamartine Loureiro, outro fazendeiro da região. ${ }^{51}$

No início desse ano houve confronto com a polícia por dois dias consecutivos. Em 25 de janeiro o soldado José Lopes recebeu vários tiros disparados por posseiros que aguardavam a ação policial na casa de Zé Genuíno. No dia seguinte, policiais de vários destacamentos de Ecoporanga entraram em confronto com posseiros tocaiados. Resultado: três policiais saíram feridos. Sebastião Nestor levou um tiro no pescoço, o soldado Natalino levou um tiro no olho e outro policial saiu ferido na perna. Em 13 de abril o tenente Jadir Resende, que era delegado de Ecoporanga, comandando 16 policiais, sem qualquer determinação judicial, adentrou a Fazenda Rezende em Itapeba (alvo de outras diligências policiais) para desalojar posseiros e invasores. ${ }^{52}$

Nesse sentido, particularmente, o ano de 1962 foi especialmente marcante no que se refere à luta camponesa em Ecoporanga. Dessa vez, a diligência do tenente Jadir foi motivada por um pedido de "providências" - através de um bilhete - do próprio Secretário do Interior e Justiça, general Darcy Pacheco de Queiroz, que queria "atender a um velho amigo". Tratava-se de José Alberto, irmão de Antônio Rezende, dono da Fazenda Rezende. José Alberto havia procurado Darcy Pacheco pedindo ajuda para expulsar os posseiros que ocupavam terras supostamente pertencentes ao seu irmão. Esse pedido motivou o bilhete escrito por Darcy Pacheco ao tenente Jadir, com os seguintes dizeres:

Aqui está comigo um velho amigo, ao qual tenho todo o interesse em servir. Aliás, a causa que ele defende é das mais justas e tem recebido todo o apoio desta Secretaria e do sr. Governador do Estado [...]. O sr. José Alberto conversará com você a respeito de uma invasão em propriedade de seu irmão - doente atualmente - e peço sua atenção e providências a respeito. ${ }^{53}$

Espancamentos, prisões e destruição de casas por meio de incêndios eram as principais características das diligências policiais quando se tratava de posseiros. Entretanto, como em outras situações, dessa vez houve reação, ocasionando a morte do soldado Alnízio Brum da Silva e ferimentos no soldado Abelar da Cunha. ${ }^{54}$ Do lado dos posseiros, uma mulher e sua filha também saíram feridas. É claro que, numa diligência dessas - estando em menor número, com um policial morto e outro ferido, além de pelo menos outras duas

\footnotetext{
${ }^{51}$ Ibidem, p. 103.

${ }^{52}$ Ibidem, pp. 97-102.

${ }^{53}$ Ibidem, p. 23.

${ }^{54}$ DIAS, op. cit., p. 102.
} 
vítimas - não havia alternativa para a polícia senão recuar e pedir reforço. A situação se agravou porque, em seguida, o fazendeiro Antônio Rezende foi baleado numa tocaia. As estradas da região foram bloqueadas e vigiadas tanto por posseiros quanto por jagunços. 0 caos estava instalado: essa era a imagem que se tinha em Vitória. As informações chegadas à capital por meio do jornal A Gazeta ${ }^{55}$ davam conta de que os posseiros invadiriam os povoados da região em represália às ameaças de pistoleiros e jagunços e à arbitrariedade policial. O general Darcy Pacheco e o comandante-geral da Polícia Militar do Espírito Santo, coronel Tércio de Moraes e Souza, foram para Ecoporanga.

Geralda Maria Maciel, ${ }^{56}$ filha de Jenuíno Gama, disse que os posseiros do Córrego do Limão ficaram sabendo do reforço policial no município e que a "Captura" iria "acabar" com eles. Alarmados e com medo, pediram para ela levar uma carta às autoridades em Ecoporanga. Segundo ela,

[...] um rapaz que se chamava Moisés Santana, que também já é falecido escreveu uma carta e me pediu para levá-la a Ecoporanga. Eu fui à delegacia de Ecoporanga onde estava o coronel Tércio de Moraes e me apresentei a ele. Cheguei a Ecoporanga, fiquei assim: com um pouquinho de receio de ir sozinha lá. Até, ainda falei com eles [os posseiros] em casa: e se eu ficar presa? - Ah! Se ficar presa nós vamos lá. Tem que prender todos nós. Aí eu fui. Cheguei lá e chamei o Nico Rosa, que era o coletor naquela época, e ele foi comigo lá na delegacia. O coronel escreveu até no verso da carta, a resposta [dizendo] que os posseiros poderiam ficar em paz, tranquilos, que a polícia não viria aqui no Córrego do Limão, que veio para ir à fazenda Rezende, em Itapeba. ${ }^{57}$

De fato, nesse período, a Polícia Militar não fez diligências no Córrego do Limão, em Cotaxé, como o coronel Tércio havia prometido. Mas, estrategicamente, deslocou-se um pelotão (sob o comando do tenente Carlos Augusto Vieira Matos) para o distrito de Estrela do Norte, "onde deveria reunir-se com o Tenente Euclides José dos Santos, que, segundo informações, comandava soldados e alguns civis que se prestaram a auxiliar os soldados; [...]. O capitão Décio Nascimento partiria com outro pelotão para Itapeba, onde posseiros mataram o soldado Brum. Um terceiro pelotão (comandado pelo tenente Wilson Pimentel Junquilho) ficaria na sede do município, junto ao comandante-geral. ${ }^{58} \mathrm{Com}$ o devido reforço policial, os resultados foram muito

\footnotetext{
${ }^{55}$ CRIMINOSOS da pior espécie fazem parte dos bandos que atacam fazendas: PM atenta. A Gazeta, Vitória, 18 abr. 1962, p. 5.

${ }^{56}$ Geralda Maria Maciel nos concedeu entrevista em Ecoporanga, ES, em 20 de abril de 2018.

${ }^{57}$ MACIEL, op. cit.

${ }^{58}$ ESPÍRITO SANTO (Estado). Assembleia Legislativa. Comissão Parlamentar de Inquérito. (CPI) de 1962. Vitória, 1961, p. 114.
} 
além do "restabelecimento da ordem pública", pois essa operação possuía todo um sentimento de vingança.

Segundo Muramatsu, ${ }^{59}$ a polícia assassinou quatro posseiros durante as novas diligências: Sebastião José da Rocha, conhecido como Sebastião Rufino; Geraldo Benedito Carlota, José Calixto dos Santos e Donatílio Leôncio de Souza. Eles, porém, não foram os únicos a serem mortos. Tais informações constam tanto na CPI de 1962 - que investigou o caso, quanto no Inquérito Policial Militar (IPM) instaurado pela Polícia Militar para apurar as mortes dos quatro posseiros. Inúmeras esposas de posseiros relataram o desaparecimento dos seus maridos naquele conflito. Os policiais negaram a violência e os assassinatos. Quase todos os posseiros ouvidos disseram que foram agredidos e ameaçados por policiais militares e jagunços ou que tiveram suas casas e plantações completamente destruídas por esses agentes.

Ao término das diligências policiais, tanto no caso da destruição do movimento udelinista quanto em relação aos acontecimentos iniciados na Fazenda Rezende, o próprio Poder Público, representado pelo governo do estado, pela Assembleia Legislativa capixaba e pela Polícia Militar do Espírito Santo tomou providências para apresentar a violência policial de forma atenuada, mascarando com isso a realidade dos fatos e buscando, simultaneamente, legitimar e preservar o seu poder. Para isso, fez-se uso, principalmente, da mídia jornalística como mecanismo de manipulação da opinião pública.

Nesse seguimento, o jornal Folha do Povo ${ }^{60}$ - órgão notadamente governista - publicado em Vitória, em reportagens no mês de março de 1953, portanto, após a destruição do Estado União de Jeová, representou Udelino Alves de Matos como agitador e subversivo; analfabeto e pregador religioso, chefe do "novo Canudos", o "novo Antônio Conselheiro". Da mesma forma, nas palavras do major Djalma Borges, publicadas nesse jornal, Udelino foi retratado como um "[...] desordeiro foragido do Estado da Bahia [...]". O objetivo da reportagem era qualificar a luta por terra na região contestada como um ato de criminosos, bandidos e fanáticos religiosos que deveriam ser combatidos pela polícia. Sob o argumento de expressar a "verdade", procurava-se, ainda, denegrir a imagem do deputado federal Wilson Cunha, futuro candidato ao governo do estado pela oposição e apoiador dos posseiros, contra quem o major Djalma Borges se defendia de supostas acusações de ameaça.

\footnotetext{
${ }^{59}$ MURAMATSU, op. cit., p. 175.

${ }^{60}$ GRAVES acontecimentos em São Francisco. Folha do Povo, Vitória, 7 de março de 1953, pp. 1 e 4.
} 
No tocante aos episódios iniciados na Fazenda Rezende em 1962, o jornal A Gazeta, que, aliás, pertencia a Carlos Lindenberg desde $1949,{ }^{61} \mathrm{em}$ reportagens publicadas em abril de 1962 afirmava que entre os posseiros havia, também, "criminosos da pior espécie". Além disso, os próprios posseiros eram representados como invasores e bandos armados, portanto igualmente criminosos. ${ }^{62}$ Entretanto, embora a polícia tenha lidado com tais indivíduos, segundo Darcy Pacheco de Queiroz, Secretário do Interior e Justiça, a situação havia sido normalizada nos vilarejos de Estrela do Norte e Itapeba, de forma "[...] inteiramente pacífica, sem que se tenha deflagrado um tiro sequer". ${ }^{63}$

Percebemos, com isso, que havia a evidente intenção de se construir uma imagem positiva de si (governo e Polícia Militar) e negativa do outro (posseiros representados como criminosos) com a finalidade de isentar o governo estadual de quaisquer responsabilidades, ao mesmo tempo em que se procurava deslegitimar e desqualificar a luta camponesa, na tentativa de fazer valer o engodo em lugar da verdade. Na prática, os posseiros foram vencidos pelo poder político e econômico, pela grilagem de terras e pela violência histórica praticada pelos grandes proprietários apoiados pelo estado, por algumas de suas instituições e por sua Polícia Militar.

\section{Considerações finais}

A análise das tensões por divisa fronteiriça entre Minas e Espírito Santo e dos conflitos por terra e poder no Contestado mineiro-capixaba permite-nos entender que a violência na região possuía raízes históricas e complexas, cujo ápice se encontra na história do tempo presente, notadamente nas décadas de 1940, 1950 e 1960, quando as Polícias Militares do Espírito Santo e de Minas Gerais quase entraram em confronto armado por jurisdição territorial. Nesse período, a região também vivenciou um quadro conflituoso gerado pelo antagonismo entre fazendeiros e grileiros de um lado e posseiros do outro, em torno da posse, do uso e da propriedade da terra.

Nesse sentido, a Polícia Militar do Espírito Santo, além de garantir a integridade territorial do estado, frente às pretensões do governo mineiro, atuou também para a manutenção e preservação da ordem pública local. Para tanto, estava funcionalmente organizada em delegacias e subdelegacias, destacamentos distritais e numa Delegacia de Capturas sediada em Barra de

\footnotetext{
${ }^{61}$ ALMEIDA, op. cit., p. 360.

${ }^{62}$ CRIMINOSOS, op. cit., p. 5.

${ }^{63}$ INVASORES fugiram da Fazenda Rezende. A Gazeta, Vitória, 19 de abril de 1962, p. 1.
} 
São Francisco. Em sua missão, a Polícia Militar capixaba, por meio de várias diligências (algumas arbitrárias) e em virtude de sua estreita relação com políticos locais e com grandes proprietários, transformou-se num dos principais agentes do medo e da violência à medida que participava ativamente a favor dos fazendeiros e grileiros da região.

Por essa perspectiva, a destruição do Estado União de Jeová, em 1953, e as represálias por conta dos acontecimentos iniciados na Fazenda Rezende, em 1962, representam as diligências em que a Polícia Militar do Espírito Santo demonstrou maior brutalidade. Após cada uma dessas ações, o Poder Público utilizou a mídia jornalística com o propósito de qualificar a luta camponesa na região, particularmente em Ecoporanga, ES, como um movimento de bandidos, criminosos e fanáticos, ao mesmo tempo em que procurava legitimar as arbitrariedades policias, numa evidente tentativa de passar o engodo no lugar da verdade.

Notamos ainda que, embora se constituíssem no lado mais fraco na luta por terra no Contestado, os posseiros reagiram de várias formas e por diversos meios às violências contra eles perpetradas. $O$ trabalho organizacional e de conscientização realizado pelo PCB na região é um bom exemplo disso. Contudo, não era o único. Os posseiros também cometeram homicídios, tocaiaram e ameaçaram policiais e fazendeiros, dentre outras formas de resistência. Contudo, foram vencidos em meio a uma violência que superou os limites da própria condição humana e da vida em sociedade, chegando, em muitos casos, ao estado de barbárie.

Artigo recebido para publicação em 27/03/2020 Artigo aprovado para publicação em 10/06/2020 